\title{
Shear strength of soil by using clam shell waste as recycle aggregate
}

\author{
Siti Hanggita Rachmawati, ${ }^{1,2}$ Zakaria Hossain, ${ }^{1}$ Jim Shiau $^{3}$ \\ ${ }^{1}$ Graduate School of Bioresources, Mie University, Japan; ${ }^{2}$ Faculty of Agriculture, Sriwijaya University, South \\ Sumatera, Indonesia; ${ }^{3}$ School of Civil Engineering and Surveying, University of Southern Queensland, Brisbane, \\ Australia
}

\begin{abstract}
Every year in Japan, industry and household consumption generate a significant amount of clam shell waste. It has inevitably imposed a negative impact on the national environment and economics. To reduce those effects, this study proposes the reutilisation of abandoned clam shell for ground improvement. An experimental study was conducted to evaluate the shear strength of this new construction material. Soils were mixed with various percentages of clam shells as well as cement. The new soil-clam shellcement samples were tested under the triaxial consolidateddrained tests (CD tests). Test results showed that the addition of clam shell and cement in the soil leads to increase deviatoric stress. Furthermore, shear strength parameters of specimens were quantified in terms of cohesion and frictional resistance. Based on the results of the current study, it was concluded that approximately $9.50 \%$ increase of frictional angle can be achieved whilst the cohesion can only be improved by $6 \%$. This new construction material can be used in the future for the base course of unpaved roads in agriculture engineering applications.
\end{abstract}

Correspondence: Siti Hanggita Rachmawati, Faculty of Agriculture, Sriwijaya University, South Sumatera, Indonesia.

E-mail: sitihanggitarj_thi@unsri.ac.id

Key words: Clam shell waste; cement; ground improvement; principal stress difference; axial strain; shear strength.

Acknowledgements: First of all, the authors much appreciate the scholarship provided by the Japanese Government (Monbukagusho: MEXT) through both Mie University and Sriwijaya University. We thank Mr. Ito that greatly assisted the research.

Received for publication: 22 December 2019.

Accepted for publication: 15 June 2020.

${ }^{\circ}$ Copyright: the Author(s), 2020

Licensee PAGEPress, Italy

Journal of Agricultural Engineering 2020; LI:1043

doi:10.4081/jae.2020.1043

This article is distributed under the terms of the Creative Commons Attribution Noncommercial License (by-nc 4.0) which permits any noncommercial use, distribution, and reproduction in any medium, provided the original author(s) and source are credited.

\section{Introduction}

Annually, enormous volume seashell-by-products (SBP) are produced in all over the world. Burning and burying are the most common way to treat those kinds of waste (Motamedi et al., 2015). All those disposal processes affect a severe problem of environment and economic perspective. An example of SBP in Japan is abandoned clam shell by total amount 151,000 tons/year which take nearly 32 million US\$ is spent on disposal (Hossain, 2013). That budget is undesirable despite Japan being a developed country. While in developing countries, many illegal dumping occurs due to the high cost of disposal waste. Most of the clam shell is usually disposed of in landfills (Figure 1A). In a long time, if this waste is not treated properly, it could cause air pollution and other environmental problems. These circumstances motivate the development of technologies using an abandoned clam shell (Motamedi et al., 2015; Yoon et al., 2009).

The utilisation of abandoned clam shell is expected to solve the main problems in environmental and economic aspects, such as: i) waste storage problem; and ii) protection of limited natural resources of aggregates (Hossain, 2013). From the point of view the potency of clam shell, it is composed mainly of $95-99 \%$ (by weight) of $\mathrm{CaCO}_{3}$ that is potentially converted into $\mathrm{CaO}$ for reinforcing the soil or binding the material (Motamedi et al., 2015; Park et al., 2014). In the previous study, the clam shell was used as a recycling aggregate for ground improvement. By using the direct shear test, the result showed that a certain amount of clam shell increased the shear strength of soil (Rachmawati and Zakaria, 2017).

In this study, the abandoned clam shell was used as the recycle aggregate for ground improvement. Ground improvement techniques are provided to increase the soil strength, to reduce compressibility, and to enhance the performance under the load. The triaxial tests are performed to evaluate the shear strength of specimens that contained soil (only), soil-clam shell, soilcement, and soil-cement-clam shell. The utilisation of cement was applied because an additional 4 to $14 \%$ of cement could improve the properties of soil (Hossain and Sakai, 2008). Furthermore, the addition of cement can be used for modified and stabilised purposes. Modified means to improve workability and compaction characteristics while the term stabilised is encouraging to improve the mechanical behaviour of cementtreated soil (Sarriosseiri and Muhunthan, 2009). In this study, all specimens are evaluated by the triaxial test. It is the most reliable method for determining shear strength parameters under different drainage conditions (Arora, 1978). The triaxial test provides information on the stress-strain behaviour of the soil that the direct shear test does not. It also provides a more uniform stress condition than the direct shear test with its stress concentration along the failure plane (Das, 2007). 


\section{Materials and methods}

Soil, clam shell, and cement are used as materials of the specimen in this research. The soil sample was taken nearby the Shiratsuka Port in Mie Prefecture Japan. Based on the results of laboratory testing using the Unified Classification System, sand was the highest part of this soil with silt and clay as another part. Both of the properties of soil and clam shell waste are given in Table 1.

Clam shell waste was collected from the seaside which to Mie University, Tsu City, Mie Prefecture, Japan. Surf clam (Mactridae) was the source of clam shell which had been used in this research. The shell of surf clam was quite strongly constructed due to its habit which likes to burrow in rocks. It is well known that surf or trough clam has a smooth surface, with concentric growth lines and covered by thin periostracum (Vaughan, 2001). The results of the sieving analysis showed that the fineness modulus and the maximum size of the abandoned clam shell were 4.35 and 4.76 $\mathrm{mm}$, respectively. The soil and shell size distribution curves are presented in Figure 1B. From a total of 16 specimens, 12 specimens contained cement percentage. The type of cement is Ordinary Portland cement (Type I), which was commonly used and easy to find in local markets. The properties of this cement can be found elsewhere (Hossain and Sakai, 2008).

All the test specimens were manually compacted inside the mold with $12.5 \mathrm{~cm}$ in height and $5.0 \mathrm{~cm}$ in diameter. The specimens were control (soil only), soil-cement percentages $(2 \%, 4 \%$, $6 \%$ ), soil-clam shell percentages $(10 \%, 20 \%, 30 \%)$, and combination of the soil-cement-clam shell by using both similar percentages previously mentioned. Further, the soil was mixed with sepa-

A

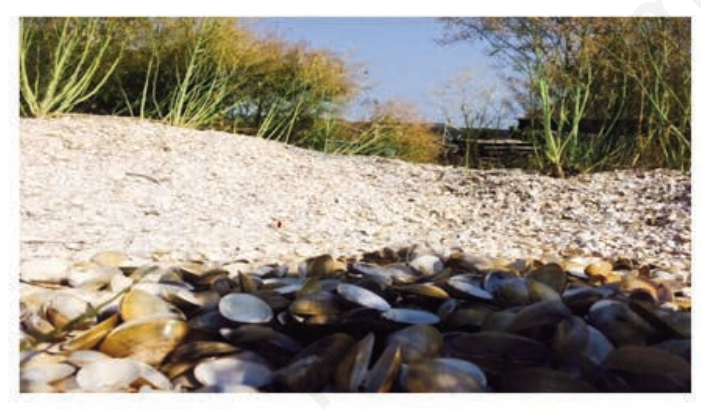

C

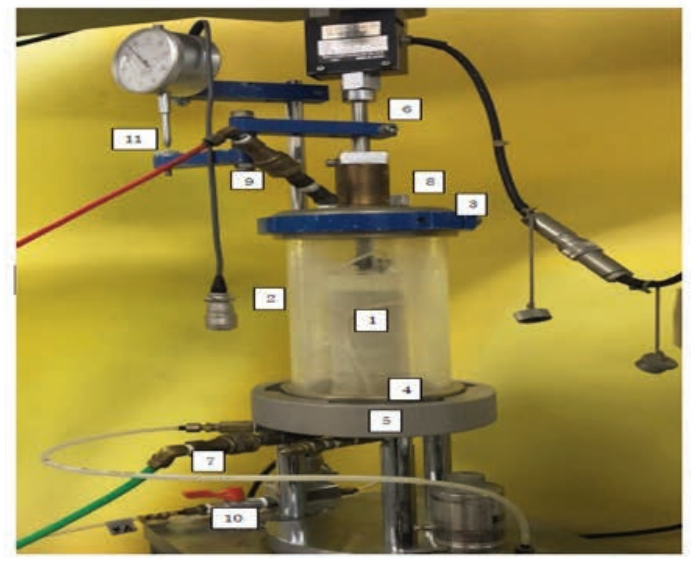

rated clam shell and cement percentages or both materials depending on the composition. The specimens were compacted in three layers using a $4.9 \mathrm{~cm}$ diameter hand-rammer with rammer mass of $1.0 \mathrm{~kg}$ and a falling height of $30 \mathrm{~cm}$. Each layer was compacted by 20 blows. The average water contents were $9 \%-12 \%$ which observed on the dry side of optimum water content. Specimens which contained cement were cured for seven days at room temperature. After that, consolidated-drain (CD) test triaxial compression tests were conducted to evaluate specimens.

\section{Testing method}

The specimens are evaluated using trixial apparatus as shown in Figure 1C. Initially, the triaxial chamber was assembled from

Table 1. Properties of soil and clam shell.

\begin{tabular}{llc} 
Particles & Parameters & Values \\
Soil particle & Dry density $\left(\rho_{d}\right)$ & $1.76 \mathrm{~g} / \mathrm{cm}^{3}$ \\
& Optimum Water Content $\left(W_{\text {opt }}\right)$ & $13.29 \%$ \\
& Specific gravity $\left(\rho_{s}\right)$ & 2.589 \\
& Cohesion $(c)$ & 60.95 \\
& Angle of internal friction $(\varphi)$ & 32.75 \\
& Sand $>75 \mu \mathrm{m}$ & $55.56 \%$ \\
& Silt $>5-75 \mu \mathrm{m}$ & $24.64 \%$ \\
& Clay $<5 \mu \mathrm{m}$ & $19.80 \%$ \\
& Liquid limit & $41.00 \%$ \\
& Plastic limit & $34.72 \%$ \\
& Plasticity Index & $6.28 \%$ \\
Clam shell & Water absorption & $7.28 \%$ \\
& Specific Gravity & 1.75 \\
& Unit Weight $\left(\mathrm{g} / \mathrm{cm}^{3}\right)$ & 1.57 \\
\hline
\end{tabular}

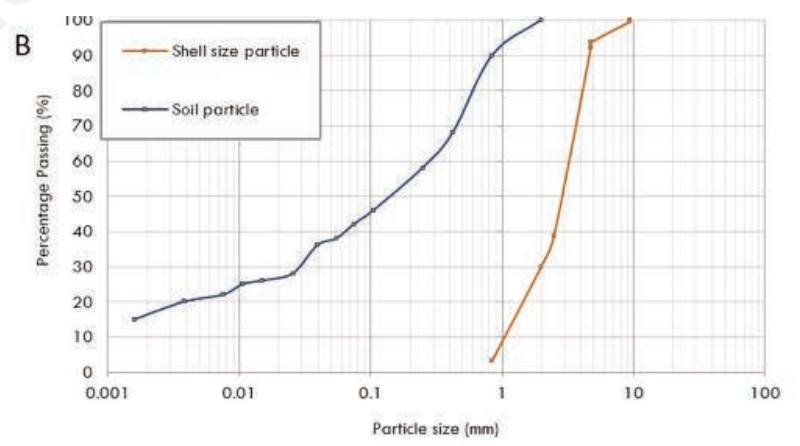

D

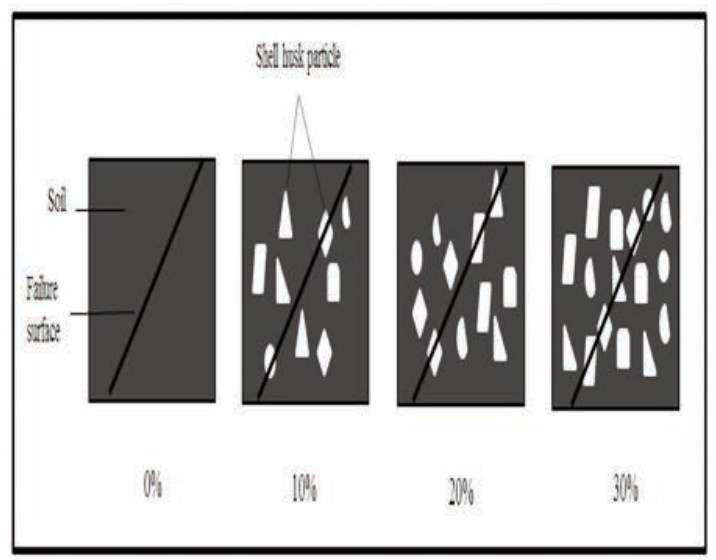

Figure 1. A) Clam shell waste; B) Particle size distribution curve; C) Triaxial apparatus; D) Failure surface of specimen soil-clam shell. 
the soil specimen sealed by the rubber membrane (1). After that, in the baseplate groove (4), the chamber cylinder was installed (2), and then, the top plate was positioned on it (3). The three components of the triaxial chamber (i.e., baseplate, chamber cylinder, and top plate) were clamped together by tightening the tie ring (5). The specimen cap has a circular indentation at the centre, and the position of loading piston (6) should be aligned. It was achieved by pushing down the loading piston and verified precisely into the centre of the specimen cap. Next, the chamber was filled with the fluid from the water channel (7), and at the same time, air releases valve on top cap kept open (8). Axial stress $(\sigma)$ was applied through the loading piston and during the process, the dial gauge (11) connected with piston and specimen recording vertical deformation. The hydrostatic chamber pressure was implemented using the air channel (9) on the top cap while the air release valve on top cap closed. The confining pressures in this research were $50 \mathrm{kPa}$, $100 \mathrm{kPa}, 150 \mathrm{kPa}, 200 \mathrm{kPa}$. During the test, the water valve (10) was kept open due to drained condition requirements in $\mathrm{CD}$ test. When the ultimate value of the principal stress difference $\left(\sigma_{\mathrm{a}}-\sigma_{\mathrm{r}}\right)$ was reached, then the test will be stopped. However, if an ultimate value was not recorded, then the peak value of the principal stress difference $\left(\sigma_{\mathrm{a}}-\sigma_{\mathrm{r}}\right)$ defined at $15 \%$ axial strain (JGS 2001).

\section{Results and discussion}

\section{The relationship between differential stress $\left(\sigma_{\mathrm{a}}-\sigma_{\mathrm{r}}\right)$ and axial strain $\left(\mathcal{E}_{\mathrm{a}}\right)$}

Figure 2 shows the relationship between axial strain $\left(\varepsilon_{\mathrm{a}}\right)$ and principal stress difference $\left(\sigma_{\mathrm{a}}-\sigma_{\mathrm{r}}\right)$ of soil composite with $0 \%, 10 \%$, $20 \%$, and $30 \%$ clam shell is illustrated. Most specimens under confining pressure $50 \mathrm{kPa}$ and $100 \mathrm{kPa}$ showed the ultimate principal stress differences $\left(\sigma_{\mathrm{a}}-\sigma_{\mathrm{r}}\right)$ then followed by softening behaviour (Figure 2A-2D). On the other hand, under confining pressures of $150 \mathrm{kPa}$ and $200 \mathrm{kPa}$, the ultimate principal stresses for other specimens were defined on $15 \%$ axial strain because the peak value had not achieved. However, soil with clam shell 30\% (Figure 2D) reached the highest principal stress difference $\left(\sigma_{\mathrm{a}}-\sigma_{\mathrm{r}}\right)$ under confining pressure $200 \mathrm{kPa}$, followed by softening behaviour shown by the peak value of axial strain (less than $15 \%$ axial strain).

The relationship between axial strain $\left(\varepsilon_{a}\right)$ and principal stress difference $\left(\sigma_{\mathrm{a}}-\sigma_{\mathrm{r}}\right)$ of the specimen which treated by $2 \%$, $4 \%$, and $6 \%$ cement addition was given in Figure 3. The graphs show cement addition led to a decrease in the axial strain of the specimen. The increasing of cement percentage developed the
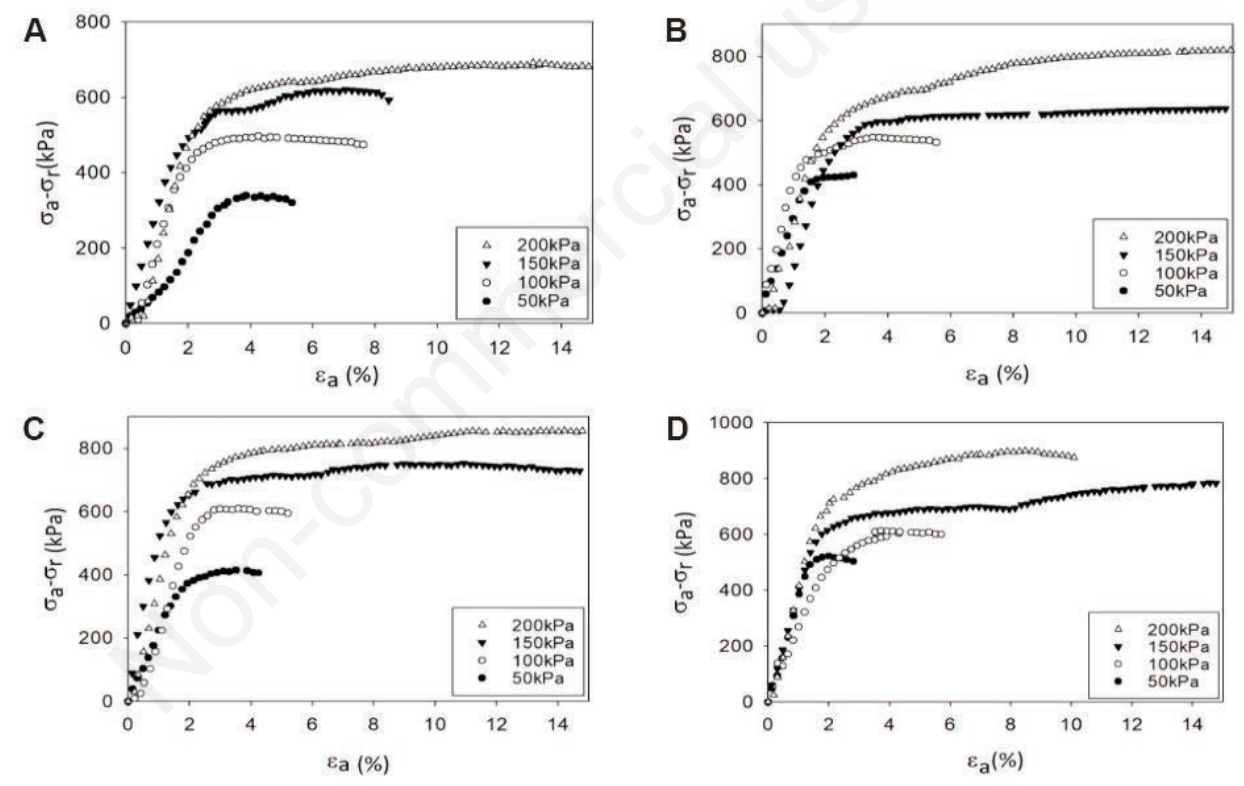

Figure 2. The relationship between axial strain $(\mathrm{Ea})$ and principal stress difference $\left(\sigma a-\sigma_{\mathrm{r}}\right)$ of soil composite with $0 \%(\mathrm{~A}), 10 \%(\mathrm{~B})$, $20 \%(C)$ and $30 \%(D)$ clam shell.
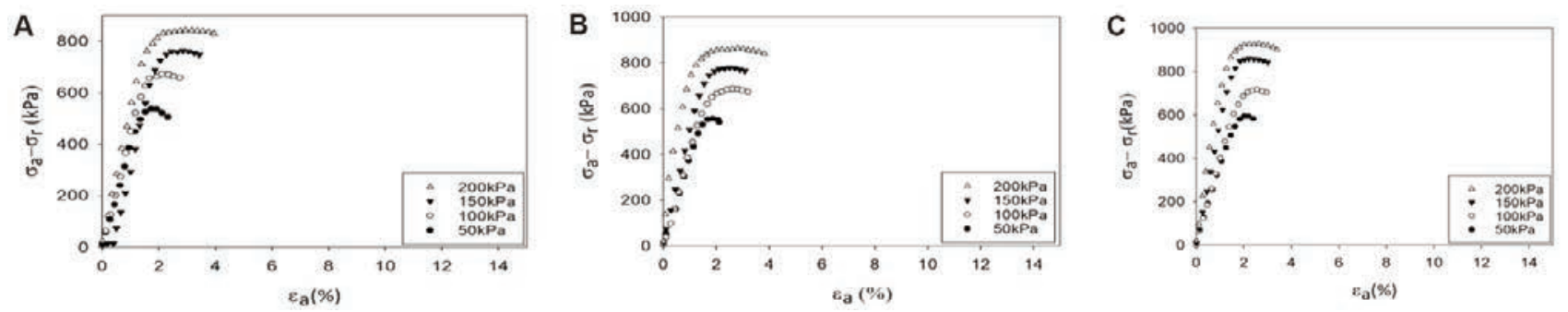

Figure 3. The relationship between axial strain $(\mathrm{Ea})$ and principal stress difference $\left(\sigma_{\mathrm{a}}-\sigma_{\mathrm{r}}\right)$ of specimen which treated by $2 \%(\mathrm{~A}), 4 \%(\mathrm{~B})$ and $6 \%(C)$ cement addition. 
principal stress difference $\left(\sigma_{\mathrm{a}}-\sigma_{\mathrm{r}}\right)$ of specimens and the highest principal stress difference $\left(\sigma_{\mathrm{a}}-\sigma_{\mathrm{r}}\right)$ had reached by the addition of $4 \%$ cement. Most of the maximal principal stress differences $\left(\sigma_{\mathrm{a}}-\sigma_{\mathrm{r}}\right)$ were defined at $4 \%$ axial strain $\left(\varepsilon_{\mathrm{a}}\right)$ (Figure $\left.3 \mathrm{~A}-3 \mathrm{C}\right)$. Furthermore, the specimens were treated by a combination of cement and clam shell (Figure 4-6), the graphs show typically the combination of clam shell-cement increasing the axial strain $\left(\varepsilon_{\mathrm{a}}\right)$, compared to the specimen using only cement (Figure 3 ).

It was observed that overall specimen behaviour was significantly affected by the addition of clam shell and cement percentage. Illustration of the relationship between axial strain $\left(\varepsilon_{\mathrm{a}}\right)$ and principal stress difference $\left(\sigma_{\mathrm{a}}-\sigma_{\mathrm{r}}\right)$ of all specimens showed that peak strength and brittleness behaviour changed due to separated or combined effects of clam shell and cement percentages. From this figure, it was known that increasing confining pressure enhances the principal stress differences $\left(\sigma_{\mathrm{a}}-\sigma_{\mathrm{r}}\right)$. Most of the soilclam shell specimens showed the ultimate principal stress differences $\left(\sigma_{\mathrm{a}}-\sigma_{\mathrm{r}}\right)$ which defined on $15 \%$ axial strain. On the other hand, soil with cement addition showed peak strength and then decreased the axial strain. It was recognised that soil treated by cement exhibited much more stiffness and brittle behaviour than non-treated soil (Consoli et al., 1998; Sariosseiri and Muhunthan, 2009). Figure 7 presents failure pattern after triaxial test for (A) control, (B) soilclam shell, (C) soil-cement, (D) soil-cement-clam shell respectively. As can be seen, the failure patterns (C) and (D) show cracking which means brittle behaviour due to cement addition.
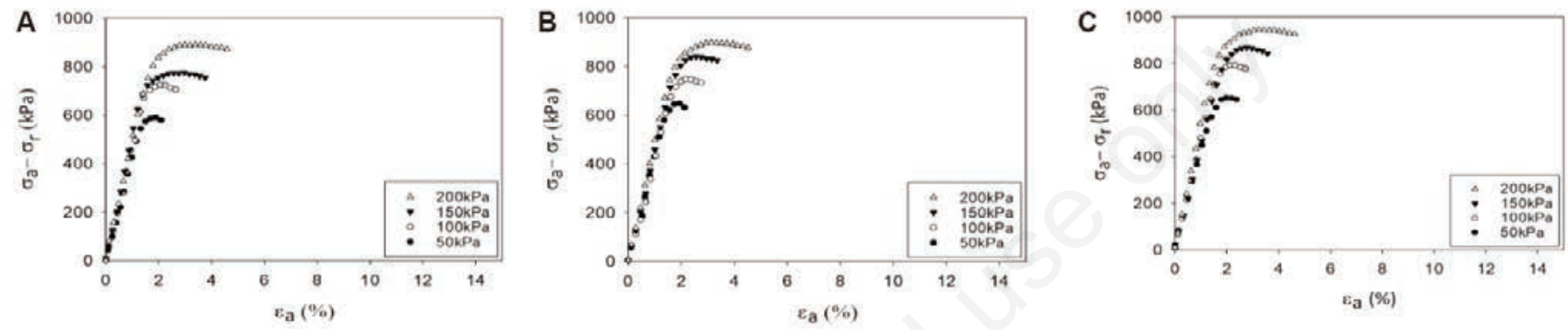

Figure 4. The relationship between axial strain $(\mathcal{E} a)$ and principal stress difference $\left(\sigma_{a}-\sigma_{r}\right)$ of specimen which treated by combination of cement addition and clam shell; $2 \%$ cement and $10 \%$ clam shell (A), $4 \%$ cement and $10 \%$ clam shell (B) and $6 \%$ cement and $10 \%$ clam shell (C).
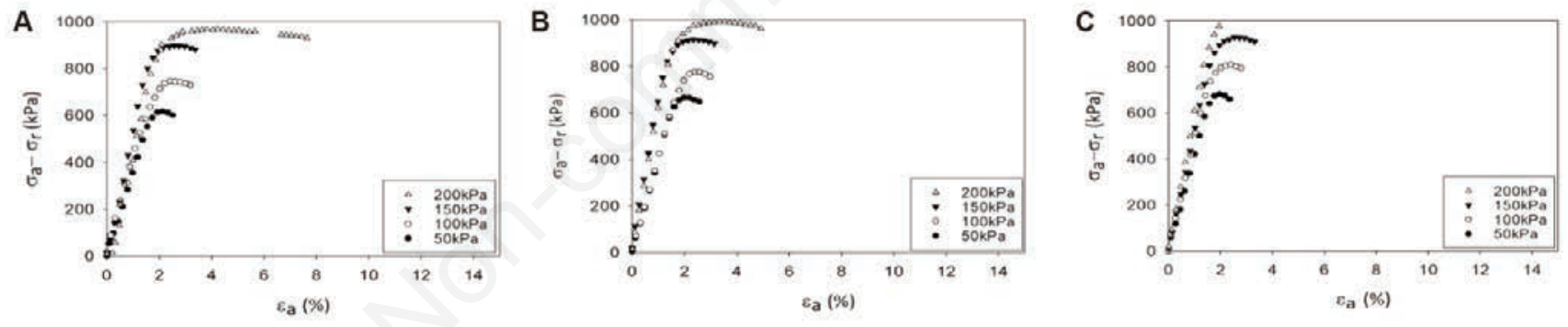

Figure 5. The relationship between axial strain $(\mathcal{E} a)$ and principal stress difference $\left(\sigma_{a}-\sigma_{r}\right)$ of specimen which treated by combination of cement addition and clam shell; $2 \%$ cement and $20 \%$ clam shell (A), $4 \%$ cement and $20 \%$ clam shell (B) and $6 \%$ cement and $20 \%$ clam shell (C).
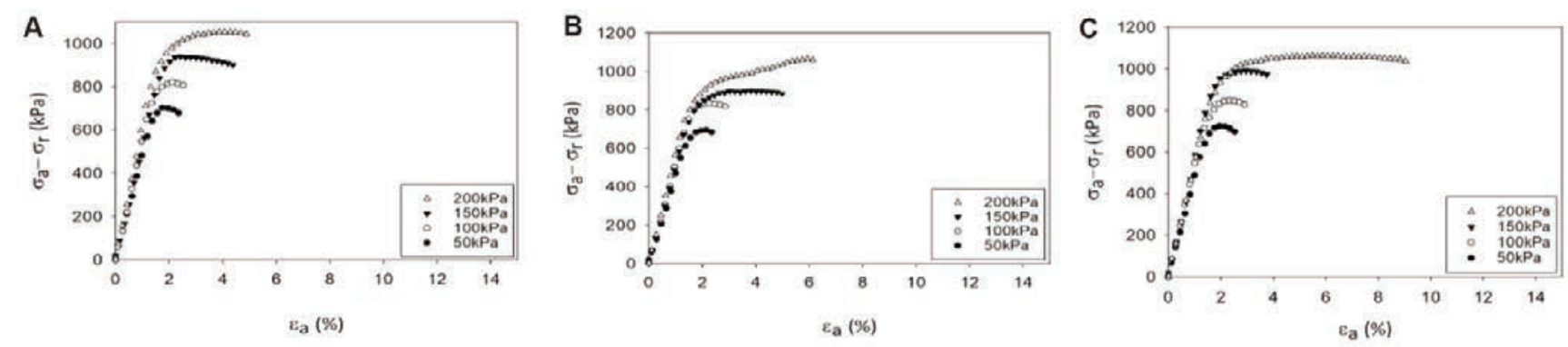

Figure 6. The relationship between axial strain $(\mathcal{E a})$ and principal stress difference $(\sigma a-\sigma r)$ of specimen which treated by combination of cement addition and clam shell; $2 \%$ cement and $30 \%$ clam shell (A), $4 \%$ cement and $30 \%$ clam shell (B) and $6 \%$ cement and $30 \%$ clam shell (C). 


\section{Shear strength of soil composition with clam shell per- centages}

The triaxial test had a failure surface that reflected the real stress-strain characteristic of samples compared to the direct shear test. In the triaxial test, several different conditions i.e. drained, undrained, consolidated, and unconsolidated can be simulated. The triaxial compression test had chosen as an accurate and reliable method by many researchers (Zhang et al., 2010). The calculations were obtained by Mohr-Coulomb criterion as a linear function of the normal stress $\left(\sigma_{f}\right)$ on the plane at the same point which followed by the equation (Mouazen et al., 2002):

$\tau_{f}=c+\sigma_{f} \tan \varphi$

An angle of internal friction $(\varphi)$ was the measure of the shear strength of soils due to friction of soil and reinforcing materials (Zhang et al., 2010). On the other hand, cohesion (c) held the particles of the soil together in a soil mass and independent of the normal stress (Arora 1978). Table 2 results are calculated by using equation 2 to obtain $(c)$ and $(\varphi)$ :

$\sigma_{a}=\sigma_{r} \tan ^{2}(45+\varphi / 2)+2 c \tan (45+\varphi / 2)$

The calculation was referred to equation 1 , where $\sigma_{a}$ and $\sigma_{r}$ were the major and minor effective principal stresses, respectively (Das, 2007).

Indexes of shear strength, the angle of internal friction $(\varphi)$ and cohesion (c) of specimens are summarised in Table 3. This table shows that clam shell addition enhanced the angle of internal friction of soil-clam shell composite. It was attributed to the irregular shape of clam shell particle which developed the frictional resistance between particles. For the specimen soil-cement-clam shell, the increase in clam shell percentage also increased the angle of internal friction. However, soil with cement addition had a lower angle of internal friction compared to control and soil with clam shell only. It may due to anti-synergetic action between the angle of internal friction and cohesion because specimens with cement addition had higher cohesion than other specimens (Hossain et al., 2006).

The enhancement of cohesion was also known as the primary function of the cementation process due to cementitious hydration. Clam shell also had an essential role to increase the cohesion of specimens up to $20 \%$ clam shell. Clam shell had $\mathrm{Ca}^{2+}$ which attracted negative ion of soil which caused interlocking mechanism between soil and clam shell particles. However, the cohesion was reduced at $30 \%$ clam shell for both specimen soil-clam shell and soil-cement-clam shell. It was realised that the high percentages $(>20 \%)$ of clam shell also increased brittle behaviour which had a consequence for the angle of internal friction and cohesion of specimen. The decreasing of soil cohesion after $20 \%$ clam shell addition occurred in previous research which observed the shear

Table 2. Ultimate principal differential stress $\left(\sigma_{\mathrm{a}}-\sigma_{\mathrm{r}}\right)$ of samples.

\begin{tabular}{lcccc} 
Samples & \multicolumn{3}{c}{ Confining pressure (kPa) } \\
& 50 & 100 & 150 & 200 \\
0\% Shell husk & 389.5 & 560.2 & 769.8 & 891.3 \\
10\% Shell husk & 480.3 & 647.9 & 787.3 & 1019.3 \\
\hline 20\% Shell husk & 464.7 & 709.5 & 902.2 & 1055.8 \\
30\% Shell husk & 572.8 & 713.5 & 934.9 & 1099.6 \\
\hline Cement 2\% & 588.6 & 771.7 & 912.7 & 1043.4 \\
Cement 4\% & 607.2 & 787.6 & 929 & 1063.7 \\
\hline Cement 6\% & 645 & 816 & 1009.4 & 1127.9 \\
10\% Shell husk (2\% Cement) & 641 & 825.3 & 926.1 & 1092 \\
\hline 10\% Shell husk (4\% Cement) & 698.7 & 848.6 & 991.8 & 1099.1 \\
10\% Shell husk (6\% Cement) & 703.3 & 892.4 & 1018.9 & 1145.8 \\
\hline 20\% Shell husk (2\% Cement) & 668.5 & 846.7 & 1049.5 & 1169.3 \\
20\% Shell husk (4\% Cement) & 717.8 & 875.9 & 1066.2 & 1192.7 \\
\hline 20\% Shell husk (6\% Cement) & 732.4 & 909.5 & 1078.7 & 1245 \\
30\% Shell husk (2\% Cement) & 753.3 & 921.4 & 1089.5 & 1253 \\
\hline 30\% Shell husk (4\% Cement) & 745.6 & 934.7 & 1051.9 & 1267 \\
30\% Shell husk (6\% Cement) & 776.1 & 948.7 & 1141.8 & 1264.3 \\
\hline
\end{tabular}

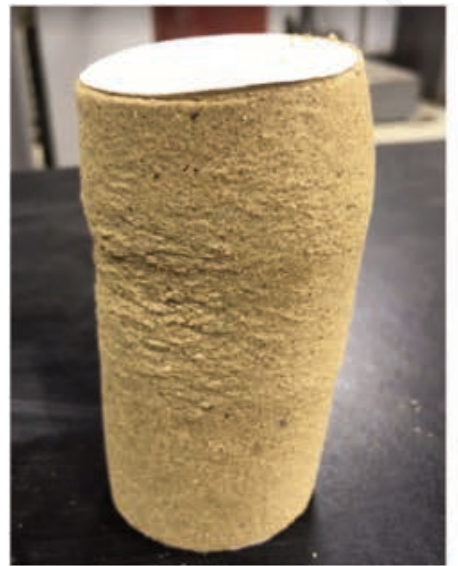

A

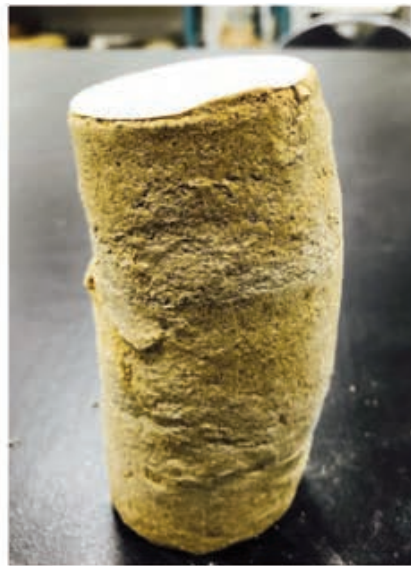

B

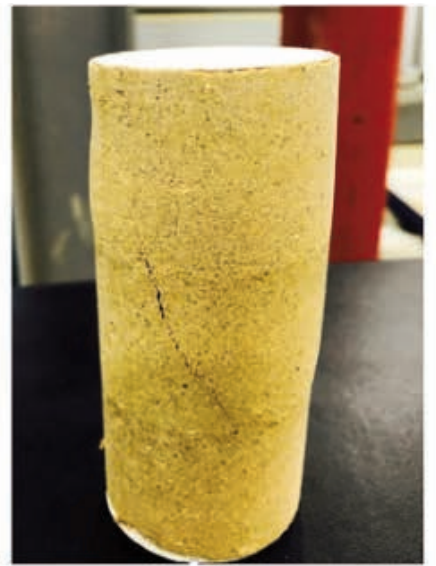

C

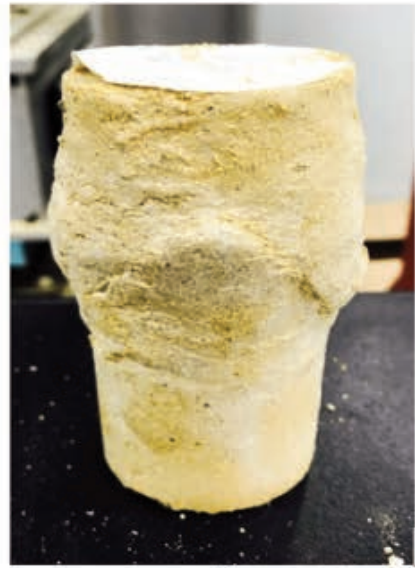

D

Figure 7. Failure pattern of samples. A) control; B) soil-clam shell; C) soil-cement; D) soil-cement-clam shell. 
strength of soil with clam shell reinforcement using a direct shear test (Rachmawati and Zakaria, 2017).

Calculation of shear strength based on the angle of internal friction and cohesion are also presented in Table 3. This table shows that clam shell percentage reinforced specimen. The reinforcement of clam shell percentage is illustrated in Figure 1D. It is explained that clam shell percentage enhanced shear strength of specimen by impeding failure surface. The results showed a specimen that had clam shell and cement percentage combination had higher shear strength than those specimens with cement addition only or clam shell addition only. Both angles of internal friction and cohesion may increase or decrease by clam shell and cement percentage addition, but generally, the final results were an increase in shear strength.

\section{Conclusions}

The effects of clam shell and cement addition into natural soils were investigated in this paper. A total of sixteen samples had been examined using the triaxial tests and the results reported concerning its principal differential stress $\left(\sigma_{\mathrm{a}}-\sigma_{\mathrm{r}}\right)$, axial strain $\left(\varepsilon_{\mathrm{a}}\right)$ internal friction $(\varphi)$, cohesion $(c)$ and shear strengths $\left(\tau_{f}\right)$. In general, the angle of internal friction increases with the increase in clam shell percentage. This is due to the nature of the various shapes of clam shell, which contribute to the friction and interlocking between particles. Nevertheless, the increases in cohesion is not pronounced which can be expected from the increased discontinuity in this new material.

It can be concluded that clam shell contributes to the improvement of the angle of internal friction while cement improves cohesion. It is, therefore, promising to see the future use of this new construction material consisting of soil, clam shell, and cement in the application of agricultural road. It is recommended that future work should be give concern to Young's Modulus of this material.

Table 3. The angle of internal friction and cohesion of specimens.

\begin{tabular}{lcc} 
Samples & $\phi$ & $c$ \\
0\% Shell husk & 32.75 & 60.95 \\
10\% Shell husk & 33.53 & 76.91 \\
\hline 20\% Shell husk & 34.15 & 93.39 \\
30\% Shell husk & 35.90 & 89.14 \\
\hline Cement 2\% & 24.11 & 117.07 \\
Cement 4\% & 24.30 & 119.79 \\
\hline Cement 6\% & 31.78 & 141.41 \\
10\% Shell husk (2\% Cement) & 28.61 & 153.37 \\
\hline 10\% Shell husk (4\% Cement) & 29.42 & 161.94 \\
10\% Shell husk (6\% Cement) & 32.14 & 162.13 \\
\hline 20\% Shell husk (2\% Cement) & 32.86 & 137.67 \\
20\% Shell husk (4\% Cement) & 33.01 & 146.71 \\
\hline 20\% Shell husk (6\% Cement) & 33.49 & 151.00 \\
30\% Shell husk (2\% Cement) & 32.78 & 159.58 \\
\hline 30\% Shell husk (4\% Cement) & 33.04 & 157.73 \\
30\% Shell husk (6\% Cement) & 34.76 & 153.54 \\
\hline
\end{tabular}

\section{References}

Agustini T.W., Fahmi A.S., Widowati I., Sarwono A. 2011. Utilisation of Asian moon scallop (Amusium pleuronectes) shell waste on making of calcium-rich cookies (in Indonesian). Indonesian Fish. Process. J. 1:8-13.

Arora K.R. 1978. Soil mechanics and foundation engineering. Standard Publishers Distributors, Nai Sarak-Delhi, India. Chapter 13.

Consoli N.C., Prietto P.D.M., Ulbrich L.A. 1998. Influence of fiber and cement addition on behaviour of sandy soil. J. Geotechn. Geoenviron. Eng. 124:1211-4.

Das B.M. 2007. Fundamentals of geotechnical engineering, 3rd ed. SI Cencage Learning, United States. Chapter 3.

Downey R., Marsh L., Flick G.J.F. Jr. 2012. The seafood industry: species, products, processing and safety, $2^{\text {nd }}$ ed. Blackwell Publishing, Ltd., London, UK, pp 76-77.

Hosain Md.Z., Narioka H., Sakai T. 2006. Effect of ordinary Portland-cement on properties of clayey soil in Mie Prefecture. J. Jpn. Soc. Soil. Phys. 103:31-8.

Hossain Md.Z., Sakai T. 2008. The effectiveness of nominal dosage of ordinary cement on strength and permeability of clayey soil. J. Jpn. Soc. Soil Phys. 110:25-35.

Hossain M.Z. 2013. Waste shell husks concrete: durability, permeability and mechanical properties. J. Build. Construct. Plann. Res. 1:61-6.

JGS 0524. 2001. Method for consolidated-drained triaxial compression test on soils, Japan Geotechnical Society. Dositsu Shiken Hou Dositsu Kogakkai: 233-43. [In Japanese].

Li H.Y., Tan Y.Q., Zhang L., Zhang Y.X., Song Y.H., Ye Y., Xia M.S. 2012. Bio-filler from waste shellfish shell: preparation, characterisation, and its effect on the mechanical properties on polypropylene composites. J. Hazard Mater. 217-218:256-62.

Motamedi S., Shamshirband S., Hashim R., Petkovic D., Roy C. 2015. Estimating unconfined compressive strength of cockle shell-cement-sand mixtures using soft computing methodologies. Engine. Struct. 98:49-58.

Mouazen A.M., Ramon H., Baerdemaker J.D. 2002. Effects of bulk density and moisture content on selected mechanical properties of sandy loam soil. Biosyst. Engine. 83:217-24.

Park K., Jun S., Kim D. 2014. Effect of strength enhancement of soil treated with environment-friendly calcium carbonate powder. Sci. World J. 2014:1-11.

Rachmawati S.H., Zakaria M.Z. 2017. Utilisation of waste shell husks for ground improvement. Int. Agric. Engine. J. 26:11-8.

Sariosseiri F., Muhunthan B. 2009. Effect of cement treatment on geotechnical properties of some Washington State soils. Engine. Geol. 104:119-25.

Vaughan. 2001. Gladys arched collection on Family: Mactridae (surf or trough clams, Mactras). Washington State University collection. Available from: http://shells.tricity.wsu.edu/ ArchedShellCollection/Bivalvia/Mactridae.html Accessed: 10 February 2018.

Yoon G.L., Yoon Y.W., Chae K.S. 2009. Shear strength and compressibility of oyster shell-sand mixtures. J. Environ. Earth Sci. 60:1701-9.

Zhang C.B., Chen L.H., Liu Y.P., Ji X.D., Liu X.P. 2010. Triaxial compression test of soil-root composites to evaluate influence of roots on soil shear-strength. Ecol. Engine. 36:19-26. 